\title{
Clinical Factors Related to the Response of IV Ferric Carboxymaltose Treatment in Patients with Restless Legs Syndrome
}

\author{
Hea Ree Park ${ }^{1}$, Hye Sun Park ${ }^{1}$, Su Jung Choi ${ }^{1,3}$, Eun Yeon Joo ${ }^{1,2}$ \\ ${ }^{1}$ Department of Neurology, Neuroscience Center, Samsung Biomedical Research Institute, Samsung Medical Center, Sungkyunkwan University \\ School of Medicine, Seoul, \\ ${ }^{2}$ Department of Health Sciences and Technology, SAIHST, Sungkyunkwan University, Seoul, \\ ${ }^{3}$ Department of Nursing, Samsung Medical Center, Department of Clinical Nursing Science, Graduate School of Clinical Nursing Science, \\ Sungkyunkwan University, Seoul, Korea
}

\section{하지불안증후군에서 Ferric Carboxymaltose 정맥 주사 치료반응과 관련된 임상 요인}

박혜리 ${ }^{1}$, 박혜선 ${ }^{1}$, 최수정1,3, 주은연 ${ }^{1.2}$

성균관대학교 의과대학 삼성서울병원 신경과, 뇌신경센터, ${ }^{1}$ 성균관대학교 삼성융합의과학원 융합의과학과, ${ }^{2}$

성균관대학교 임상간호대학원 삼성서울병원 간호부 ${ }^{3}$

Received April 23, 2018 Revised May 16, 2018 Accepted June 2, 2018

Address for correspondence Eun Yeon Joo, MD, PhD Department of Neurology,

Neuroscience Center, Samsung Medical Center, Sungkyunkwan University School of Medicine, 81 Irwon-ro, Gangnam-gu, Seoul 06351, Korea Tel: $+82-2-3410-3597$ Fax: +82-2-3410-0052 E-mail: ejoo@skku.edu
Objectives: Significant benefit of intravenous ferric carboxymaltose (FCM) for restless legs syndrome (RLS) has been demonstrated. However, clinical indicators to expect treatment response of RLS are not clarified. The aim of this study is to find out determinant factors to predict treatment outcome of FCM. Methods: We enrolled consecutive 108 patients with RLS who visited sleep clinic and received FCM from April 2016 to November 2017. Obtained data were detailed history including international restless legs scale (IRLS) and questionnaires, comorbid diseases, medication. Complete blood cell count, serum iron, ferritin, and total iron-binding capacity were sampled before and after treatment. Treatment response was assessed about four weeks after FCM administration. Patients with more than $40 \%$ decrease on IRLS were classified into the responders. Results: 99 patients (mean 54.5 y and 79 females) were included. 58 patients (58.6\%) were classified to be responders. There were substantial differences in post-treatment IRLS and symptom reduction rate between responders $(7.4 \pm 6.4,77.5 \pm 18.6 \%)$ and non-responders $(29.7 \pm 8.7,7.4 \pm 10.3 \%)$. No significant differences were found in demographics, baseline IRLS, sleep, and mood status between two groups. Serum ferritin and transferrin saturation was significantly lower in responders $(37.6 \mathrm{ng} / \mathrm{mL}, 25.0 \%)$ than non-responders $(55.1 \mathrm{ng} / \mathrm{mL}, p=0.014$ and $36.5 \%, p=0.001)$. Patients with a history of gastrectomy $(n=8)$ showed an excellent response to FCM (83.8\% of symptom reduction). Comorbid lumbosacral radiculopathy had lower response rate (29.4\%). Conclusions: Peripheral iron compromised state and gastrectomy history may indicate good response to intravenous FCM in patients with RLS. Patients with lumbosacral radiculopathy tend to be poor responders to intravenous FCM.

J Sleep Med 2018;15(1):8-14

\section{서 론}

하지불안증후군(restless legs syndrome, RLS)은 다리를

This is an Open Access article distributed under the terms of the Creative Commons Attribution Non-Commercial License (https://creativecommons.org/licenses/by-nc/4.0) which permits unrestricted non-commercial use, distribution, and reproduction in any medium, provided the original work is properly cited.
움직이고 싶은 견딜 수 없는 충동과 하지 또는 상지의 불편 하고 불쾌한 감각 증상으로 움직이는 감각-운동 신경계 질 환이다. RLS와 뇌내 철 부족 간의 연관성이 밝혀지면서, RLS 환자에서 철분 보충치료와 관련된 임상 연구들이 시행되었 다. ${ }^{1-9}$ 철분 보충치료는 크게 경구철분제와 철분 정맥 주사로 나뉘며, 주사 제제는 경구 제제에 비해 더 빠르게 작용하고 
소화기 부작용 등의 환자가 느끼는 불편감이 적은 것이 장점 이어서 최근 많이 이용되고 있다. ${ }^{5,8}$

가장 최근에 개발된 ferric carboxymaltose(FCM) 제제는 덱스트란 성분이 포함되지 않은 안정 복합체로서 면역반응 유발의 가능성이 낮고, 아나필락시스의 위험이 낮기 때문에 단시간에 고용량 투여가 가능하다. ${ }^{10}$ 현재까지 RLS에서 철분 주사를 이용하여 시행된 다섯 개의 무작위 이중 눈가림 위약 대조군 연구가 있다. Sucrose 제제를 이용한 두 개의 연구에 서는 대조군에 비하여 유의한 효용성을 입증하지 못한 반면, FCM 제제를 이용한 세 개의 연구에서는 모두 대조군에 비 하여 뚜렷한 RLS 증상 완화 효과를 나타냈다.,7-9,11 최근 발 표된 RLS의 철분 보충치료에 대한 치료지침에서는, 트랜스 페린 포화도(transferrin saturation)가 45\% 이하이면서 혈청 페리틴이 $100 \mathrm{ug} / \mathrm{L}$ 미만인 중등도 이상의 RLS에서 경구철 분제에 효과가 없거나 부작용으로 복용할 수 없는 경우, 빠른 치료효과가 필요한 경우 FCM 제제를 이용한 철분 주사 치료 를 권고하고 있다. ${ }^{12}$ 아직까지 $\mathrm{FCM}$ 정맥 주사의 치료효과를 예측할 수 있는 임상 요인은 밝혀져 있지 않다. 한 연구에서 젊은 연령 및 혈청 페리틴 수치와 $\mathrm{FCM}$ 투여 후 증상 호전 사 이의 연관성을 보였으나, 다른 연구들에서는 일관된 결과가 없었다. ${ }^{13} \mathrm{FCM}$ 제제를 이용한 세 개의 무작위 위약대조군 연 구들에서는 치료반응군과 치료비반응군 간에 연령과 혈청 페 리틴 수치의 유의한 차이가 관찰되지 않았다. 일 개의 연구에 서만 트랜스페린 포화도와 $\mathrm{FCM}$ 치료반응 간의 연관성이 관 찰되었다. $8,9,11$ 그 외 RLS의 동반질환과 FCM 치료반응 간의 연관성에 관한 연구는 거의 없다.

본 연구진들은, 말초혈액 내 철분 부족 상태인 환자들이 RLS 에서 FCM 치료반응이 더 좋을 것으로 가정하였으며, 그 외에 환자의 동반질환들에 의해서도 치료반응이 영향을 받을 것이 라고 가정하였다. 이를 증명하기 위하여 RLS 환자에서 $\mathrm{FCM}$ 의 치료반응성을 바탕으로 치료반응군과 치료비반응군으로 분류한 후, 치료결과와 연관성 있는 임상적 요인을 조사하고 자 하였다.

\section{방 법}

\section{대 상}

본 연구는 의무기록을 이용한 후향적 연구로, 2016년 4월 부터 2017년 11월까지 본원 수면 클리닉에 내원한 환자들이 연구에 포함되었다. 모든 연구대상자들은 정형화된 수면 및 기분장애 설문지에 응답했고 동반질환과 약물 복용력을 보 고했으며, 신경학적 검사와 혈액검사를 받았다. 선정 기준은 International RLS study group에서 제안한 기준에 따라 진
단된 성인 RLS 환자들 중 상기 기간 내에 $\mathrm{FCM}$ 주사 치료를 받은 환자이며, 선정 제외 기준은 다음과 같다: ${ }^{14} 17$ 세 미만 의 소아 환자; 외래 추적관찰이 되지 않는 등 치료 후 증상 변화를 조사할 수 없는 환자; 혈청 페리틴 > $300 \mathrm{ng} / \mathrm{mL}$; 이 전에 철분 주사 제제 투여의 이력이 있는 환자. 또한 $\mathrm{FCM}$ 투 여 이전에 RLS를 진단받고 이에 대한 약물치료를 하던 환자 들도 본 연구에 포함되었으며, 그러한 경우에는 기존 약물은 유지한 상태로 FCM 투여를 하였고 4주 뒤 치료반응을 평가 한 후 임상적 필요에 따라 약물이 조정 혹은 중단되었다.

본 연구에 사용된 모든 연구 기준과 방법 및 평가는 삼성 서울병원 임상윤리심의위원회의 임상시험윤리심의를 획득 하였으며, 임상윤리심의위원회의 관리감독하에 시행되었다 (2017-12-082-001).

\section{설문지 및 혈액검사}

환자는 수면 각성 습관, 피츠버그 수면질지수(Pittsburgh Sleep Quality Index, PSQI), 불면증 심각도지수(Insomnia Severity Index, ISI), 엡워스 주간졸림증 척도(Epworth Sleepiness Scale, ESS)가 포함된 수면 설문지와 RLS 증상의 정량적 평가를 위해 국제하지불안척도(International Restless Legs Scale, IRLS) 및 우울과 불안 증상 평가지(Hospital Anxiety and Depression Scale, HADS)를 작성하였다. 의료진은 RLS 의 시작 연령, 유병 기간, 증상 발생 빈도, 가족력과 요천추 신 경근병증, 당뇨병, 위절제술 등의 동반질환을 조사했다. $\mathrm{FCM}$ 투여 전후로 혈액검사를 통해 complete blood cell count, 혈 청 철, 페리틴, 총철결합능을 측정했다.

\section{$\mathrm{FCM}$ 정맥 주사 투여 및 치료반응 평가}

모든 환자들에게 $\mathrm{FCM} \mathrm{1,000} \mathrm{mg을} \mathrm{정맥} \mathrm{주사하였다.} \mathrm{치료}$ 반응성은 FCM 투여 4주 뒤 시행한 IRLS 평가를 기준으로 판 단하였다. 투여 후 IRLS가 $40 \%$ 이상 감소한 연구대상자들을 치료반응군(responders)으로 분류하였으며, IRLS 점수가 10점 이하인 대상자들을 관해군(remitters)으로 분류하였다. 89,113,15 RLS 증상 변화 평가를 위해 IRLS 외에도 보완적으로 ' $\mathrm{FCM}$ 투여 후 하지불안 증상이 얼마나 감소했나요'라는 질문을 통 해 주관적으로 느끼는 증상 호전율(\%)을 함께 조사하였다.

\section{통계 분석}

연구대상자의 특성 및 동반질환은 평균과 표준편차를 이 용하거나 백분율을 사용하여 나타냈고, 비교 항목 중 편차가 크고 비정규 분포를 보이는 항목들은 중앙값과 구간값을 이 용해 제시했다. 치료반응군과 비반응군 간의 특성 차이는 연 속 변수에 대해서는 정규 분포 여부에 따라 independent $\mathrm{t}-$ 
test 혹은 Mann-Whitney test를 사용하고 범주변수에 대해서 는 chi-square test로 분석하였다. 인구학적 변수 및 혈액검사 수치들과 증상 감소율 혹은 IRLS 감소치와의 연관성은 스피 어만 상관분석을 통하여 분석하였다. 통계 분석은 SPSS version 18.0(SPSS Inc., Chicago, IL, USA)을 이용하였고 $p$ 값이 0.05 미만인 경우 통계적으로 유의한 것으로 판정하였다.

\section{결 과}

총 108 명의 연구대상자가 등록되었으며 이 중 제외 기준 에 해당하는 9명을 뺀 99명의 환자들을 대상으로 분석을 시

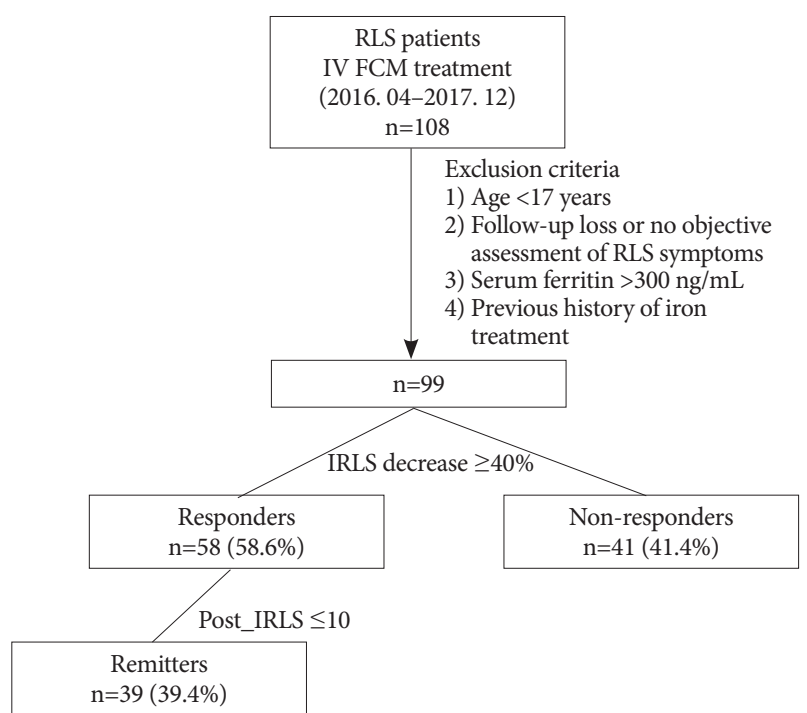

Figure 1. Study protocol. RLS: restless legs syndrome, FCM: ferric carboxymaltose, IRLS: international restless legs scale.
행하였다. 이 중 58 명 $(58.6 \%)$ 의 환자들이 치료반응군에 해당하 였으며 나머지 41명(41.4\%)은 치료비반응군(non-responders) 으로 분류되었다. 치료반응군 중 관해군에 속하는 환자들은 39명(39.4\%)이었다(Fig. 1).

\section{대상자 특성}

환자들의 평균 연령은 54.5세이고 이 중 여성은 79명(79.8\%) 이었다. 치료 전 IRLS 점수는 30.7 \pm 8.3 점으로 중등도 이상 의 증상을 호소했으며, 주관적 수면의 질 저하(평균 PSQI $10.6 \pm 4.3$ )와 높은 수준의 불면증(평균 ISI 15.8土8.4)이 동반 되었다. 또한 이들 중 37명(37.4\%)의 환자들은 RLS 약물을 복용 중이었다. 치료반응군과 치료비반응군 간의 임상적 특성 비교는 Table 1에 정리되어 있다. 양군 간의 인구학적 특성과 RLS 병력 간의 차이는 없었다. RLS의 가족력과 기존 RLS 약 물 복용의 비율도 군 간 차이가 없었다. 치료 전 IRLS, 수면 관 련 설문평가 및 우울, 불안 증상 평가도 양군 간 유의한 차이 가 없었다.

치료 전 혈청 페리틴 수치가 치료반응군에서 치료비반응군 에 비해 유의하게 낮았다[37.6(14.4-57.9) ng/mL vs. 55.1(27.467.4) $\mathrm{ng} / \mathrm{mL}, p=0.024]$ (Fig. 2). 치료반응군의 혈청 철 수치[75.0 (43.0-103.0) $\mu \mathrm{g} / \mathrm{dL}$ vs. 106.5(64.8-147.8) $\mu \mathrm{g} / \mathrm{dL}, p=0.001]$ 와 트랜스페린 포화도[25.0(11.0-32.0)\% vs. 36.5(23.0-49.3)\%, $p=0.001]$ 도 치료반응군에서 더 낮았으며, 총철결합능은 치료 반응군에서 더 높았다[322(294-374) $\mu \mathrm{g} / \mathrm{dL}$ vs. 297(264-328) $\mu \mathrm{g} / \mathrm{dL}, p=0.006]$. 혈청 페리틴 수치가 $<10 \mathrm{ng} / \mathrm{mL}$ 로 매우 낮 았던 환자들은 모두 8명이었으며, 이들 중 6명(75\%)이 치료 반응군에 해당되었다.

Table 1. Clinical characteristics

\begin{tabular}{lccc}
\hline & Responders $(\mathrm{n}=58)$ & Non-responders $(\mathrm{n}=41)$ & $p$-value* \\
\hline Age, years & $52.7 \pm 17.1$ & $56.9 \pm 15.7$ & 0.217 \\
Female, \% & 77.6 & 82.9 & 0.615 \\
Onset age, years & $42.0 \pm 17.6$ & $46.3 \pm 18.6$ & 0.285 \\
Disease duration, years & $12.2 \pm 13.2$ & $10.9 \pm 13.4$ & 0.654 \\
Pittsburgh sleep quality index & $10.3 \pm 4.4$ & $11.0 \pm 4.3$ & 0.596 \\
Epworth Sleepiness Scale & $8.5[4.0-13.0]$ & $6.0[4.25-8.75]$ & 0.199 \\
Insomnia severity index & $14.4 \pm 7.1$ & $17.4 \pm 9.5$ & 0.175 \\
HADS_anxiety & $8.1 \pm 4.3$ & $9.6 \pm 5.2$ & 0.302 \\
HADS_depression & $7.6 \pm 5.2$ & $8.2 \pm 4.4$ & 0.655 \\
Insomnia (ISI >14), \% & 39.4 & 57.1 & 0.204 \\
Family history of RLS, $n$ (\%) & $7(12.1)$ & $10(24.4)$ & 0.175 \\
RLS medication, $n(\%)$ & $20(34.5)$ & $17(41.5)$ & 0.531 \\
\hline
\end{tabular}

Responders, IRLS score decrease $\geq 40 \%$; non-responders, IRLS score decrease $<40 \%$. Mean \pm standard deviation or medain [25-75 percentile range]. *independent t-test/Mann-Whitney test for continuous measures, chi-square test for categorical data. HADS: hospital anxiety and depression scale, ISI: insomnia severity index, RLS: restless legs syndrome, IRLS: international restless legs scale 

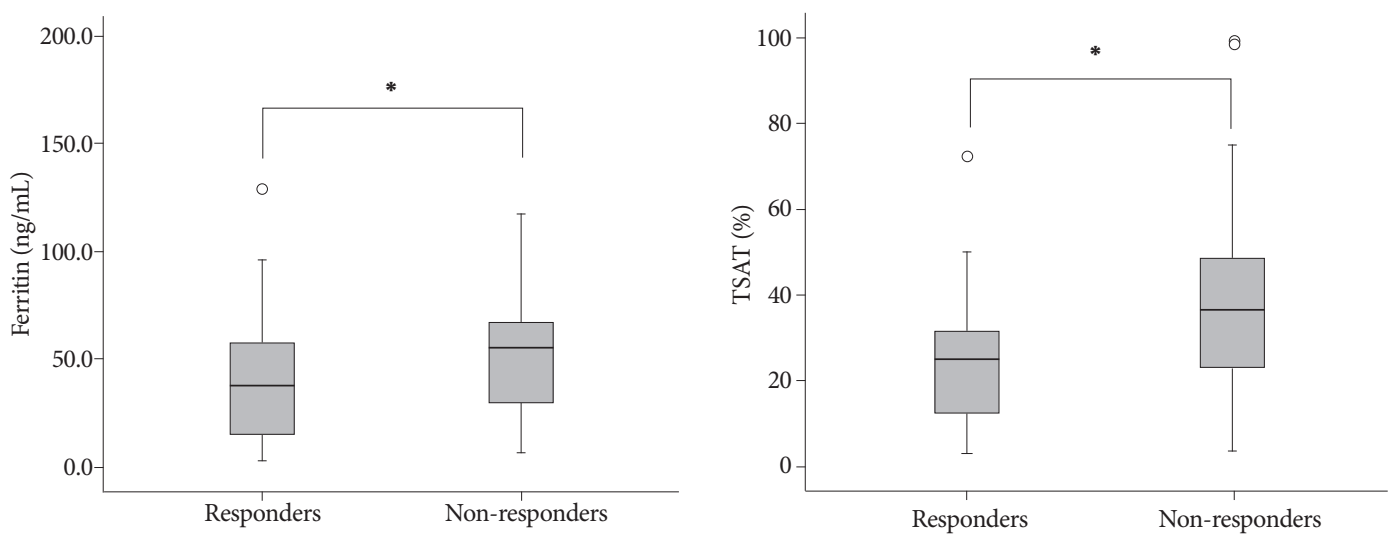

Figure 2. Serum ferritin level and TSAT before intravenous ferric carboxymaltose treatment. Responders, IRLS score decrease $\geq 40 \%$; nonresponders, IRLS score decrease $<40 \%$. ${ }^{*} p$ value $<0.05$. TSAT: transferrin saturation, IRLS: international restless legs scale.

Table 2. Effect of ferric carboxymaltose treatment on restless legs syndrome symptoms and peripheral iron panel

\begin{tabular}{|c|c|c|c|}
\hline & Responders $(\mathrm{n}=58)$ & Non-responders $(n=41)$ & $p$-value* \\
\hline \multicolumn{4}{|l|}{ IRLS, \% } \\
\hline Pre-treatment & $29.8 \pm 8.3[24.5-39.5]$ & $32.0 \pm 8.2[24.0-40.0]$ & 0.190 \\
\hline Post-treatment & $7.4 \pm 6.4[3.0-12.0]$ & $29.7 \pm 8.7[23.0-36.0]$ & $<0.001^{\dagger}$ \\
\hline$-\Delta$ difference & $74.9 \pm 20.0[61.3-97.5]$ & $9.7 \pm 16.1[0.0-16.0]$ & $<0.001^{\dagger}$ \\
\hline Subjective symptom reduction rate, $\%$ & $77.5 \pm 18.6[70.0-100]$ & $7.4 \pm 10.3[0.0-10.0]$ & $<0.001^{\dagger}$ \\
\hline \multicolumn{4}{|l|}{ Serum ferritin, ng/mL } \\
\hline Pre-treatment & $40.0 \pm 27.2[14.4-57.9]$ & $53.6 \pm 31.9[27.4-67.4]$ & $0.014^{\ddagger}$ \\
\hline Post-treatment & $356 \pm 184[203-474]$ & $396 \pm 125[276-440]$ & 0.475 \\
\hline$\Delta$ difference & $318 \pm 190[145-453]$ & $341 \pm 128[238-395.9]$ & 0.628 \\
\hline \multicolumn{4}{|l|}{ Serum iron, $\mu \mathrm{g} / \mathrm{dL}$} \\
\hline Pre-treatment & $75.5 \pm 38.3[43.0-103.0]$ & $142 \pm 171[64.8-148]$ & $0.001^{\dagger}$ \\
\hline Post-treatment & $273 \pm 366[95.0-132]$ & $119 \pm 37.0[100-138]$ & 0.842 \\
\hline$\Delta$ difference & $246 \pm 406[17.0-104.0]$ & $23.7 \pm 28.0[8.0-35.0]$ & 0.197 \\
\hline \multicolumn{4}{|l|}{ Total iron binding capacity, $\mu \mathrm{g} / \mathrm{dL}$} \\
\hline Pre-treatment & $334 \pm 51.7[294-374]$ & $313 \pm 145[264-328]$ & $0.006^{\dagger}$ \\
\hline Post-treatment & $275 \pm 39.0[248-296]$ & $271 \pm 41.5[247-303]$ & 0.799 \\
\hline$-\Delta$ difference & $54.4 \pm 28.1[29.3-77.0]$ & $162 \pm 253[52.8-98.8]$ & 0.162 \\
\hline \multicolumn{4}{|l|}{ Transferrin saturation, \% } \\
\hline Pre-treatment & $23.9 \pm 13.7[11.0-32.0]$ & $63.7 \pm 126[23.0-49.3]$ & $0.001^{\dagger}$ \\
\hline Post-treatment & $42.0 \pm 24.4[29.0-44.0]$ & $36.0 \pm 9.5[28.5-43.5]$ & 0.774 \\
\hline$\Delta$ difference & $27.5 \pm 29.0[4.0-42.0]$ & $10.8 \pm 7.7[8.0-11.0]$ & 0.480 \\
\hline
\end{tabular}

Responders, IRLS score decrease $\geq 40 \%$; non-responders, IRLS score decrease $<40 \%$. Mean \pm standard deviation [25-75 percentile range]. *independent t-test/Mann-Whitney test, ${ }^{\dagger} p<0.01,{ }^{\ddagger} p<0.05$. IRLS: international restless legs scale

\section{$\mathrm{FCM}$ 치료 전후 상태 변화 비교}

치료 전 IRLS 점수에는 군 간 차이가 없었지만, 치료 후에는 치료반응군의 점수가 현저히 낮았다(IRLS 7.4 \pm 6.4 vs. $29.7 \pm$ 8.7, $p<0.001)$. 치료반응군의 치료 전후 주관적 증상 감소율 은 $77.5 \pm 18.6 \%$ 였고 치료비반응군은 $7.4 \pm 10.3 \%$ 로 큰 차이 가 있었다 $(p<0.001)$. 치료 전 혈청 페리틴, 철 수치 및 트랜 스페린 포화도는 치료반응군에서 유의하게 더 낮았지만, 치
료 후 혈청 페리틴과 철 수치 및 트랜스페린 포화도, 총철결 합능은 군 간 차이가 없었다(Table 2).

\section{임상 요인과 $\mathrm{FCM}$ 치료효과 간의 상관분석}

연령, 성별, 발병 연령, 치료 전 IRLS, 혈청 페리틴, 철 및 트 랜스페린 포화도와 증상 감소율 또는 IRLS 감소치 간의 상 관관계를 분석했을 때, 치료 후 증상 감소율과 혈청 철 수치 
Table 3. Comorbid conditions

\begin{tabular}{lccc}
\hline & Responders $(\mathrm{n}=58)$ & Non-responders $(\mathrm{n}=41)$ & $p$-value* \\
\hline Lumbosacral radiculopathy, $\mathrm{n}(\%)$ & $5(8.6)$ & $12(29.3)$ & $0.013^{\dagger}$ \\
Gastrectomy, $\mathrm{n}(\%)$ & $8(13.8)$ & $0(0.0)$ & $0.019^{\dagger}$ \\
Diabetes, $\mathrm{n}(\%)$ & $3(5.2)$ & $2(4.9)$ & 1.000 \\
\hline
\end{tabular}

Responders, IRLS score decrease $\geq 40 \%$; non-responders, IRLS score decrease $<40 \%{ }^{*}{ }^{*}$ chi-square test, ${ }^{\dagger} p<0.05$. IRLS: international restless legs scale

사이에 음의 상관관계가 관찰되었다(rho $=-0.22, p=0.038)$.

\section{동반질환}

요천추 신경근병증은 치료비반응군에서 유의하게 높은 비 율로 동반되었고( $8.6 \%$ vs. $29.3 \%, p=0.013)$, 위절제술의 이력 이 있는 환자들은 모두 치료반응군에 속했다(13.8\% vs. $0.0 \%$, $p=0.019)$. 당뇨병의 동반 비율은 군 간 차이가 없었다 $5.2 \%$ vs. $4.9 \%, p=1.000$ )(Table 3).

본 연구에 포함된 위절제술의 이력이 있는 8 명의 환자들 은, 위절제술 후 4 20년이 경과한 상태였으며 평균 연령 70세 이고 $62.5 \%$ 가 남성으로 전체 대상군과는 다른 인구학적 특성 을 보였다. 그러나, 치료 전 페리틴 수치는 전체 대상군과 차 이가 없었다.

\section{고 찰}

본 연구는 RLS 환자에서 $\mathrm{FCM}$ 정맥 주사 치료의 효과를 확인하고 치료반응군의 임상적 특성을 조사한 연구로, 대상 환자의 $57.6 \%$ 가 $\mathrm{FCM}$ 투여 후 치료반응을 보였으며, 치료반 응군의 환자들은 상대적으로 낮은 혈청 페리틴 수치를 보였 고 위절제술의 병력을 갖는 환자들의 비율이 높은 반면, 신경 근병증의 동반 비율은 낮은 특성을 보였다. FCM을 투여한 이전 2개의 무작위 위약대조군 연구들을 보면, 치료반응군은 각각 45.8\%(11/24명)와 59.4\%(19/32명), 관해군은 각각 $25 \%$ 와 $31.3 \%$ 였다. ${ }^{89}$ 본 연구의 최종 대상자 99 명의 $58.6 \%$ 인 58 명 의 환자가 치료반응군이었고, 관해군은 $33.7 \%$ 인 33 명이어서, 이전 연구들과 유사했다.

본 연구에서는 IRLS 점수와 주관적 증상 호전율을 함께 평가했으며, 두 수치 모두 치료반응군과 치료비반응군 간에 큰 차이를 보였다. IRLS 설문지에는 RLS 증상 외 '하지불안 증후군으로 인한 수면장애' 질문도 포함되어 있다. 그런데 RLS와 불면증이 공존하는 일부의 환자에서는 $\mathrm{FCM}$ 투여 후 RLS 증상이 호전되어도 불면 증상이 남아 있을 경우, 이 질 문을 혼동하여 높은 점수를 주기도 한다. 이 문제를 보완하기 위하여 RLS 증상 호전율 질문을 추가한 것이, 기존 연구와의 차이점이다.
양군 간 임상적 특성 비교에서, 치료반응군의 혈청 페리틴 및 철 수치, 트랜스페린 포화도가 현저히 낮았고, 위절제술 의 병력이 있는 모든 환자들이 치료반응군인 반면, 요천추 신경근병증이 동반된 환자들은 대부분 치료비반응군으로 분 류되었다. 이러한 특성은 관해군의 임상 요인을 분석했을 때 도 일관되게 나타났다. 39 명의 관해군 환자들의 평균 연령은 51.8 세, 여성의 비율은 $76.9 \%$ 로 전체 환자의 인구학적 특성 과 유사했다. 혈청 페리틴의 중앙값은 $39.4 \mathrm{ng} / \mathrm{mL}$ 로 치료반 응군의 값보다 훨씬 낮았고, 요천추 신경근병증이 동반된 환 자들은 포함되지 않았다. 특히, 8 명의 위절제술 이력이 있는 환자들 중 6명 $(75 \%)$ 이 관해군에 해당되어, 가장 좋은 치료반 응을 보였다. 경구철분제를 투여한 이전의 연구에서는 페리 틴 수치가 정상 이하인 철결핍성 빈혈 환자들과 혈청 페리틴 이 정상하 범위(15 75 ng/mL)의 환자들에게서 치료효과가 입증되었다. 하지만, FCM 정맥 주사 치료를 시행한 기존 연 구들에서는 혈청 페리틴이 $300 \mathrm{ng} / \mathrm{mL}$ 이하인 환자들에서도 뚜렷한 증상 호전이 있었다. ${ }^{89}$ 혈청 페리틴 수치와 치료반응 간 유의한 관련성은 관찰되지 않았는데, 이는 말초혈액의 철 분 수치가 뇌 안의 철분 수준을 정확히 반영하지 못하기 때문 으로 주장했다. ${ }^{16,17}$ 반면 본 연구에서는 치료반응군에서 혈청 페리틴, 철, 트랜스페린 포화도가 유의하게 낮았고 총철결합 능은 증가되었으며 혈청 철 수치와 증상 감소율 간에 유의한 선형관계를 나타내어 치료반응성과 말초혈액 내 철분 부족 간의 높은 연관성을 확인하였다. 본 결과에 대한 가설을 추정 해 본다면, 기존 연구들에 비해 훨씬 많은 대상자 수로 인한 통계력의 증가를 들 수 있겠다. 본 연구에서 치료반응군의 혈 청 페리틴과 철 수치의 범위 및 평균 수치가 기존 연구들보다 낮다는 점, 혈청 페리틴 수치가 매우 낮은 RLS 환자들이 다 수 포함된 점들도 결과에 영향을 주었을 것으로 추정한다.

RLS 환자의 동반질환과 FCM 치료반응과의 관련성에 대해 서는 아직 밝혀진 바가 없다. 본 연구에서는 위절제술 이력과 요천추 신경근병증 동반 여부가 치료반응과 유의한 관련이 있 었다. 위절제술을 시행한 이력이 있는 환자들은 평균 $83.8 \%$ 의 증상 감소율을 보여서 가장 높은 $\mathrm{FCM}$ 치료반응성을 보였다. 위절제술을 시행하면, 수술 급성기에는 잠혈에 의한 혈액 손 실과 경구 섭취 제한에 의한 철결핍이 발생한다. 철분은 위산 
에 의해 흡수되기 쉬운 형태의 ferrous 이온으로 변환되어 십 이지장과 근위부 공장에서 흡수된다. 위절제와 십이지장 우 회술을 시행하면, 철분 흡수가 줄게 되고 위산 분비도 줄어서 적정 산도가 맞춰지지 못하게 되어, 철분 흡수 제한이 가중 된다. ${ }^{18}$ 철결핍성 빈혈이나 페리틴 감소는 수술 후 최소 3 년 이상 지났을 때부터 시작이 되기 때문에, 대부분의 환자들은 RLS 증상과 수술 병력 간의 연관성을 생각하지 못한다. 따라 서 위절제술을 시행한 환자들에서는 먼저 문진을 통해 RLS 동반 여부를 면밀히 관찰해야 하며 증상 의심 시 적극적인 철분 보충치료가 필요하다.

요천추 신경근병증이 동반된 17 명의 환자 중 5명(29.4\%)만 이 $\mathrm{FCM}$ 치료반응을 보였으며, $\mathrm{FCM}$ 치료에 증상이 호전되 지 않았던 12 명의 환자들 중 5 명이 추후 외래에서 도파민 길 항제를 복용하면서 증상이 호전되었다. 기존의 연구에서 요 추신경병증이 동반된 RLS 환자의 $68.1 \%$ 가 약물치료에 반응 하지 않았고 수술적 치료 후 RLS 증상도 같이 호전되었다고 한다. ${ }^{19}$ 이 치료반응의 차이는 신경근병증이 동반된 RLS 환 자들에게서 나타나는 병태생리의 차이에 의한 것으로 추정되 는데, 중추신경계 철분 부족 외에 만성통증 및 염증에 의한 싸이토카인 분비 변화가 중추신경계 내 도파민 전달에 영향 을 미쳤을 가능성이 있다. 요천추 신경병증이 동반된 환자들 의 연령은 전체에 비해 상대적으로 높았다. 이 환자들은 하지 불안증후군에 의한 다리 증상과 신경근병증에 의한 허리와 다리의 증상을 명확하게 구분하지 못하는 경우가 많다. 따라 서 IRLS 설문지나 FCM에 의한 증상 호전율을 제대로 평가 하지 못하여 치료효과를 전반적으로 낮게 평가했을 가능성도 있다. 따라서 신경근병증이 동반된 RLS 환자에서 철분 보충 치료가 효과가 없는 경우에는 도파민 길항제 투여와 함께 신 경근병증에 대한 치료를 보다 적극적으로 시도해야 함을 시 사한다.

본 연구의 제한점으로는 $\mathrm{FCM}$ 투여 4주 후 1 회만 측정하 여 비교적 짧은 시점의 치료효과만 관찰한 것이다. 기존의 연 구에서는 투여 6 12주 경과한 시점까지 평가한 반면, 본 연구 에서는 장기간에 걸친 연속적 증상 변화 결과를 살피지 않았 다. 하지만, $\mathrm{FCM}$ 투여 후 비교적 빠른 시간 안에 의미 있는 치 료효과를 평가할 수 있다는 본 결과는 진료 계획 수립에 도움 을 줄 것으로 기대한다. 기존 복용하던 도파민 계통 약물이나 기저질환에 대한 배제가 이루어지지 않은 점도 제한점이다. 본 연구의 $37.4 \%$ 의 환자들은 기존 RLS에 대한 약물치료를 받 고 있었고, $\mathrm{FCM}$ 투여 후 증상 호전 여부에 따라 투여 약물을 중단 혹은 감량 복용하였다. 함께 복용하던 RLS 치료약물이 치료결과에 영향을 주었을 가능성이 있다. 실제 진료환경에 서 접하는 RLS 환자들은 다양한 기저질환 및 치료력을 가지
고 있다. 본 연구는 기존 RLS 약물치료에 반응이 없는 환자 들에서도 $\mathrm{FCM}$ 투여를 적극적으로 시도해 볼 수 있다는 점에 서 의의를 가진다.

본 연구의 목적은 RLS 환자에서 FCM 주사 치료의 효과를 확인하고 치료반응군의 특성을 규명하는 것으로, 기존의 연 구에서 제한적인 결과를 보였던 치료반응군과 치료비반응군 간 혈청 철분 상태를 포함한 임상적 차이점을 밝힌 것에 의 의가 있다. 또한 실제 진료 환경에서 접하는 다양한 동반질 환 및 약물들을 함께 조사하여 대상자 특성에 반영함으로써, 추후 RLS 환자 치료 시 치료반응 예측 및 치료대상자 선정에 도움을 줄 수 있을 것이다. 결론적으로, 낮은 혈청 페리틴 수치 와 위절제술의 병력을 갖는 환자들에게는 보다 적극적으로 $\mathrm{FCM}$ 치료를 고려하여야 한다. 반면, 요천추 신경근병증이 동 반된 RLS 환자에게서는 $\mathrm{FCM}$ 치료와 신경근병증에 대한 치 료를 병행해야 한다.

\section{Acknowledgments}

This research was supported by Basic Science Research Program through the National Research Foundation of Korea funded by the Ministry of Science, ICT \& Future Planning, Republic of Korea (2017R1A2B4003120) and by Samsung Biomedical Research Institute grant (SMX1170571).

\section{REFERENCES}

1. Allen RP, Earley CJ. Restless legs syndrome: a review of clinical and pathophysiologic features. J Clin Neurophysiol 2001;18:128-147.

2. Nordlander NB. Therapy in restless legs. Acta Med Scand 1953;145: 453-457.

3. Davis BJ, Rajput A, Rajput ML, Aul EA, Eichhorn GR. A randomized, double-blind placebo-controlled trial of iron in restless legs syndrome. Eur Neurol 2000;43:70-75.

4. Wang J, O’Reilly B, Venkataraman R, Mysliwiec V, Mysliwiec A. Efficacy of oral iron in patients with restless legs syndrome and a low-normal ferritin: a randomized, double-blind, placebo-controlled study. Sleep Med 2009;10:973-975.

5. Earley CJ, Heckler D, Allen RP. The treatment of restless legs syndrome with intravenous iron dextran. Sleep Med 2004;5:231-235.

6. Grote L, Leissner L, Hedner J, Ulfberg J. A randomized, double-blind, placebo controlled, multi-center study of intravenous iron sucrose and placebo in the treatment of restless legs syndrome. Mov Disord 2009; 24:1445-1452.

7. Earley CJ, Horská A, Mohamed MA, Barker PB, Beard JL, Allen RP. A randomized, double-blind, placebo-controlled trial of intravenous iron sucrose in restless legs syndrome. Sleep Med 2009;10:206-211.

8. Allen RP, Adler CH, Du W, Butcher A, Bregman DB, Earley CJ. Clinical efficacy and safety of IV ferric carboxymaltose (FCM) treatment of RLS: a multi-centred, placebo-controlled preliminary clinical trial. Sleep Med 2011;12:906-913.

9. Cho YW, Allen RP, Earley CJ. Clinical efficacy of ferric carboxymaltose treatment in patients with restless legs syndrome. Sleep Med 2016;25:1623.

10. Friedrisch JR, Cançado RD. Intravenous ferric carboxymaltose for the treatment of iron deficiency anemia. Rev Bras Hematol Hemoter 2015; 37:400-405.

11. Trenkwalder C, Winkelmann J, Oertel W, et al. Ferric carboxymaltose in patients with restless legs syndrome and nonanemic iron deficiency: a randomized trial. Mov Disord 2017;32:1478-1482. 
12. Allen RP, Picchietti DL, Auerbach M, et al. Evidence-based and consensus clinical practice guidelines for the iron treatment of restless legs syndrome/Willis-Ekbom disease in adults and children: an IRLSSG task force report. Sleep Med 2018;41:27-44.

13. Hornyak M, Scholz H, Kiemen A, Kassubek J. Investigating the response to intravenous iron in restless legs syndrome: an observational study. Sleep Med 2012;13:732-735.

14. Walters AS. Toward a better definition of the restless legs syndrome. The International Restless Legs Syndrome Study Group. Mov Disord 1995; 10:634-642.

15. Trenkwalder C, Benes H, Poewe W, et al. Efficacy of rotigotine for treatment of moderate-to-severe restless legs syndrome: a randomised, double-blind, placebo-controlled trial. Lancet Neurol 2008;7:595-604.
16. Earley CJ, Connor JR, Beard JL, Malecki EA, Epstein DK, Allen RP. Abnormalities in CSF concentrations of ferritin and transferrin in restless legs syndrome. Neurology 2000;54:1698-1700.

17. Mizuno S, Mihara T, Miyaoka T, Inagaki T, Horiguchi J. CSF iron, ferritin and transferrin levels in restless legs syndrome. J Sleep Res 2005;14: 43-47.

18. Lim CH, Kim SW, Kim WC, et al. Anemia after gastrectomy for early gastric cancer: long-term follow-up observational study. World J Gastroenterol 2012;18:6114-6119.

19. Kocabicak E, Terzi M, Akpinar K, Paksoy K, Cebeci I, Iyigun O. Restless leg syndrome and sleep quality in lumbar radiculopathy patients. Behav Neurol 2014;2014:245358. 